$\begin{array}{lll}\text { Postprint version } & : & 1.0 \\ \text { Journal website } & : & \text { https://www.cambridge.org/core/journals/prehospital-and-disaster- } \\ & & \text { medicine } \\ \text { Pubmed link } & : & \text { https://www.ncbi.nlm.nih.gov/pubmed/31826788 } \\ \text { DOI } & : & \text { https://doi.org/10.1017/S1049023X19005181 }\end{array}$

This is a Nivel certified Post Print, more info at nivel.nl

\title{
Defining and Operationalizing Disaster Preparedness in Hospitals: A Systematic Literature Review
}

\author{
Marlous L.M.I. Verheul ${ }^{1}$, Michel LA Dückers, PhD $^{2,3}$ \\ 1. University Medical Centre Utrecht, Utrecht, The Netherlands \\ 2. ARQ National Psychotrauma Centre, Diemen, The Netherlands \\ ${ }^{3 .}$ Nivel - Netherlands Institute for Health Services Research, Utrecht, The Netherlands
}

\begin{abstract}
Introduction: Societies invest substantial amounts of resources on disaster preparedness of hospitals. However, the concept is not clearly defined nor operationalized in the international literature.

Aim: This review aims to systematically assess definitions and operationalizations of disaster preparedness in hospitals, and to develop an all-encompassing model, incorporating different perspectives on the subject.

Methods: A systematic search was conducted in five databases: Scopus, PubMed, Web of Science, Disaster InformationManagement Research Centre, and SafetyLit. Peerreviewed articles containing definitions and operationalizations of disaster preparedness in hospitals were included. Articles published in languages other than English, or without available full-text, were excluded, as were articles on prehospital care. The findings from literature were used to build a model for hospital disaster preparedness.

Results: In the included publications, 13 unique definitions of disaster preparedness in hospitals and 22 different operationalizations of the concept were found. Although the definitions differed in emphasis and width, they also reflected similar elements. Based on an analysis of the operationalizations, nine different components could be identified that generally were not studied in relation to each other. Moreover, publications primarily focused on structure and process aspects of disaster preparedness. The aim of preparedness was described in seven articles.

Discussion/Conclusion: This review points at an absence of consensus on the definition and operationalization of disaster preparedness in hospitals. By combining elements of definitions and components operationalized, disaster preparedness could be conceptualized in a more comprehensive and complete way than before. The model presented can guide future disaster preparedness activities and research.
\end{abstract}


Defining and Operationalizing Disaster Preparedness in Hospitals: A Systematic Literature Review: Verheul, M.L.M.I, Dückers, M.L.A. Prehospital and Disaster Medicine: 2020, 35(1), p.

\section{Introduction}

Disaster, man-made or natural, can occur at any time anywhere in the world. From 2005 through 2014, the total damage world-wide as calculated by the United Nations Office for Disaster Risk Reduction (UNISDR; Geneva, Switzerland) was US\$1.4 trillion, with 0.7 million people killed and 1.7 billion people affected. ${ }^{1}$ The risk of exposure to natural hazards and climate change, terrorism, and epidemics with serious health consequences is likely to increase. Internationally, society spends an enormous amount of money and effort on disaster preparedness: attempts to reduce vulnerabilities of communities, to be able to deal with the consequences of disasters, and to recover from the effects of disasters. ${ }^{2,3}$ Within disaster preparedness, health care plays an indispensable role, since disasters lead to large numbers of people seeking medical attention. ${ }^{4,5}$ Within health care disaster preparedness, hospitals deserve separate consideration. Their role in disasters is vital in that they provide definitive, life-saving, and emergency care for the injured. ${ }^{6}$

The significance of disaster preparedness in hospitals is not debated; however, different authors seem to approach the subject differently, with different levels of analysis and different degrees of complexity. For instance, some authors try to develop frameworks for disaster response in health care, ${ }^{7}$ while others focus on the individual employee in the health care organizations, ${ }^{8}$ or on instruments to measure public health preparedness. ${ }^{9}$

\section{[Table 1]}

\section{[Table 2]}

Differences in focus, approach, and complexity are potential obstacles for the transfer of knowledge and lessons learned between scholars, but more importantly, they can hinder the development of actual preparedness in hospitals. In order to help hospitals to prepare for disaster, a common basis is needed.

This study sought to contribute to that common basis by a systematic assessment of definitions and operationalizations of disaster preparedness in hospitals and, subsequently, by developing an allencompassing model incorporating different perspectives on the subject.

\section{Methods}

\section{Databases and Search Strategy}

A systematic review of the relevant literature was conducted, based on the guidelines of the Preferred Reporting Items for Systematic Reviews and Meta-Analyses (PRISMA). To identify relevant studies, an electronic search in five scientific databases - Scopus (Elsevier; Amsterdam, Netherlands); PubMed (National Center for Biotechnology Information, National Institutes of Health; Bethesda, Maryland USA); Web of Science (Thomson Reuters; New York, New York USA); Disaster Information Management Research Center (DIMRC; Bethesda, Maryland USA); and SafetyLit (SafetyLit Foundation Inc.; San Diego, California USA) - was performed. The searches were initially conducted in 2017, with a final update and check in December 2018. The search strategy was based on a combination of search terms in title and abstract (Table 1 and Table 2). A research librarian worked with the reviewers to develop the search strategy and select appropriate databases for the search.

\section{Eligibility Criteria and Selection}

Peer-reviewed studies with disaster preparedness concepts, definitions, criteria, or operationalizations in a hospital setting were included. In this research, operationalization is used in the meaning Greenwood gave to the term: "To operationalize a concept is to identify those variables 
Defining and Operationalizing Disaster Preparedness in Hospitals: A Systematic Literature Review: Verheul, M.L.M.I, Dückers, M.L.A. Prehospital and Disaster Medicine: 2020, 35(1), p.

in terms of which the phenomenon $(:::)$ can be accurately observed. Variables thus identified become the indexes of the phenomenon." ${ }^{10}$

Studies published in languages other than English, or with no full-text available, were excluded, as were articles that described themes other than health care, works outside an emergency or crisis context, or articles on prehospital care. Screening took place in three rounds. During the first round, two authors ( $M V$ and $M D$ ) independently screened articles retrieved on title and abstract, based on the inclusion and exclusion criteria, and decided on eligibility by consensus. In the second round, the full-texts of the selected studies were screened. Reading the full-texts revealed that some terms were missing in the original search string. For this reason, an additional search (Table 2) was conducted in the same five databases.

\section{Data Extraction and Analysis}

For each included study, a data extraction form was filled out to systematically extract information on the year of publication, journal, country of origin, general focus of the paper, preparedness definitions (quoted directly from the study), preparedness operationalizations, and the aims of preparedness. After having extracted and structured the definitions, operationalization, and aims presented in the works, a model for hospital disaster preparedness was developed. The intention beforehand was to create a conceptual model, reflecting perspectives and components recognized as relevant by different authors, as well as the interrelations between the components, and to make, if possible, a distinction between the essential features of preparedness on the one hand and their determinants on the other.

\section{Results}

\section{Number of Studies Found}

The original search yielded 2,057 articles (Figure 1). The first author screened these for doubles (338). All titles and abstracts of the remaining 1,719 were screened by both authors for relevance and significance. Both researchers agreed on the exclusion of 1,318 articles, the inclusion of 175 articles, and were undecided in 226 cases. All undecided cases were included. These 401 articles were screened in full-text in round two by the first author, while the second author checked samples.

The extended search resulted in an additional 21 articles, which were again screened by both reviewers based on title and abstract for relevance and significance. In this third round, six extra articles were included.

After the full-text screening of 407 articles, a total of 375 articles were excluded for various reasons. Articles that focused on prehospital preparedness, for instance, were not deemed relevant to answer the research question and were excluded for that reason. The screening of the reference lists of all articles led to five extra articles to be included.

The final search in December 2018 followed the same steps as described above and yielded three more articles. Eventually, the total screening process yielded 40 articles to be included in this study.

\section{Description of Included Studies}

Appendix 1 (available online only) contains data extracted from each included study using data extraction forms. The publication years of the articles included in the study ranged from 2004-2018, thus spanning more than one decade. The studies were found in 25 different journals, with authors from six different countries. The general focus of the studies has lain on measuring or assessing hospital disaster preparedness in 16 of the studies, while the other 24 studies focused on the effects of preparedness activities $(N=4)$, the definition of preparedness $(N=3)$, or other related themes $(N$ $=17$ ). 
Defining and Operationalizing Disaster Preparedness in Hospitals: A Systematic Literature Review: Verheul, M.L.M.I, Dückers, M.L.A. Prehospital and Disaster Medicine: 2020, 35(1), p.

\section{[Figure 1]}

\section{Findings on Preparedness Definitions}

Table 3 gives an overview of the original definitions found in the literature. ${ }^{8,9,11-21}$ of the 40 articles included in this study, 13 provided an original definition of preparedness and five authors referred to definitions from other articles. ${ }^{22-26}$ Definition was defined as "a statement that explains the exact meaning of a word or phrase. ${ }^{27}$ The articles included in this study contained 13 different definitions of preparedness. What these definitions had in common was that they described preparedness in terms of: (1) an action (managing, ${ }^{15}$ planning, ${ }^{21}$ or maintaining ${ }^{13}$ ); (2) aimed at minimizing or reducing ${ }^{16}$ certain consequences (challenges in general, or more specifically: increased and potentially unusual medical needs of affected populations, overwhelmed routine capabilities, or a progressive influx of patients ${ }^{8,13-15}$ ); that (3) needed to be carried out adhering to particular quality criteria: effective, appropriate, constructive, adequately, or quickly. ${ }^{11}$

\section{[Table 3]}

Findings on Operationalization of Preparedness

Four articles referred to operationalizations in other articles. ${ }^{28-31}$ Table $47,8,14,17,24,25,32-47$ shows the 22 articles that gave an original operationalization of preparedness in hospitals.

Analysis of the operationalizations leads to nine recurring components in the operationalizations in Table 5.

\section{Findings on the Aims of Disaster Preparedness}

Seven articles described the aim of disaster preparedness (Table 6). ${ }^{8,12,19,23,29,30,47}$

\section{Discussion}

\section{Definitions}

The objective of this review was to describe how disaster preparedness in hospitals has been defined and operationalized in international literature. The 40 articles included in this study contained 13 different definitions of preparedness - apparently authors feel little need to define what preparedness is, and if they feel this need, it is not common to refer to definitions developed by international colleagues. What these definitions collected in this review have in common is that they describe preparedness in terms of: (1) an action; (2) aimed at minimizing or reducing certain consequences; that (3) needs to be carried out adhering to particular quality criteria.

The context of the author that gave the definition may have influenced the content and wording of that definition. Further research needs to take these contextual differences into account, since that will positively influence the exchange of insights related to the subject of disaster preparedness in hospitals. Researchers propose that stakeholders involved in hospital preparedness activities carefully consider these aspects when operationalizing hospital preparedness in their own contexts.

\section{Operationalizations}

What these definitions do not provide is an indication of how to prepare. They are not informative about how to observe, measure, or promote preparedness. The operationalizations of disaster preparedness offer more clues.

An examination of the operationalizations of disaster preparedness in the articles yielded nine recurring components (or indexes in terms of Greenwood - which does justice to the idea that scores per component can range from high to low). ${ }^{10}$ So, disaster preparedness can be observed, measured, 
Defining and Operationalizing Disaster Preparedness in Hospitals: A Systematic Literature Review: Verheul, M.L.M.I, Dückers, M.L.A. Prehospital and Disaster Medicine: 2020, 35(1), p.

and promoted by taking at least nine different components into account. In the articles included in this study, not one author covered all nine components. The authors' emphasis might be an expression of their habits, beliefs, and ideas about disaster preparedness in hospitals. It is like the old tale in Sufism about the blind men and the elephant: every individual author describes preparedness using personal experiences that onlycapture an aspect of location of the animal. Only the combinationof all observations enables to sketch an image of the wholeelephant or, in the context of this study, the broader concept of disaster preparedness.

\section{Synthesis and Model Construction}

The next step is to synthesize the results and to use them to create a conceptual model, reflecting perspectives and components recognized as relevant by different authors, as well as the interrelations between the components. The definitions inTable 3 consider preparedness as a capability or capacity torespond to health needs and morbidities disaster-affected populations (external focus) and the ability to stay operational under critical conditions when the demand for care and the availability of time and resources is scarce (internal focus). The analysis of the operationalizations resulted in the nine components listed in Table 5. In the disaster preparedness nonagon, as shown in Figure 2, these components form the center of the model. A first assumption based on the literature review is that all components matter when it comes to understanding the preparedness status and the potential for improvement in different health care contexts.

\section{[Table 4]}

\section{[Table 5]}

\section{[Table 6]}

Secondly, although the studies provide little information on the associations between the components, it is imaginable that they are all interrelated in a certain way and that activities aimed at enhancing one particular component should be considered in relation to other components. Disaster plans and protocols that, for example, consider crisis communication and public engagement strategies, should also anticipate on the availability of staff and equipment and measures aimed at continuity and staff safety. The second assumption - the idea that components should be approached in combination - is not supported by scientific evidence yet and is to be verified.

Thirdly, since the essential features of preparedness are likely to depend on particular determinants, an outer ring with conditions was added to the model. The material analyzed in this article contains little detailed information on specific conditions, although some authors approach education, training, and exercise as such (Table 3 and Table 4). In that case education, training, and exercise can be seen as a characteristic of preparedness as well. An alternative position is that these activities are conditions for the status of the nine components/indices. Both positions can be defended. At the moment, the nature and the working mechanisms of the conditions for preparedness and the nine components clearly deserves more study in order to strengthen the evidence base of hospital preparedness. A fourth assumption, namely, is that education, training, and exercise contribute to preparedness and its components. Nevertheless, at the moment, little is known about the effects of education, training, and exercises on the level of preparedness. ${ }^{48,49}$ This also applies to the knowledge about the effects on preparedness on the actual performance during real disasters and major incidents. 
Defining and Operationalizing Disaster Preparedness in Hospitals: A Systematic Literature Review: Verheul, M.L.M.I, Dückers, M.L.A. Prehospital and Disaster Medicine: 2020, 35(1), p.

The fifth assumption is that it is important to approach the preparedness components in the center of the model in relation to a particular aim - without well-defined aim, it is impossible to disentangle the value of resources invested on the preparedness level.

Whether in the context of the model or not, the nine components should be developed through further research. Although the assumptions behind the model need to be tested, in its current form, the model can add focus in aligning the efforts of hospitals and other health care institutions, professionals, educators and trainers, policy-makers, and researchers to assess and enhance disaster preparedness.

\section{Limitations}

This review has several limitations. One could question the interpretation of the definitions and operationalizations as described in the article. Second, because only articles written in English were included, the researchers may have missed some valuable information in articles written in other languages. Third, the researchers focused on publications in peer-reviewed journals, and did not extensively look for grey literature, thus possibly missing some information. Fourth, as the absence of a preparedness definition or operationalization was an exclusion criterion, it is possible that the researchers overlooked interesting articles that did not explicitly define or operationalize preparedness. Fifth, the researchers cannot be certain that all elements of disaster preparedness where captured in the nonagon, since they only included elements found in literature. Sixth, the article focusses only on disaster preparedness in hospitals, leaving other equally important areas, such as Emergency Medical Services, undiscussed. Finally, the nonagonmodel as visualized is the result of an attempt to structure different factors and the relations between them. Obviously, alternative interpretations are possible. It is important to further develop and test models like these. The ultimate test of any preparedness model is how well it predicts the actual performance of professionals and organizations during disasters.

\section{[Figure 2]}

\section{Conclusion}

The aim of this research was to contribute to establishing a common basis for disaster preparedness in hospitals. Besides a modest number of definitions, the literature review pointed at nine preparedness components that could be brought together in a conceptual disaster preparedness model. The results of this synthesis can guide hospitals and other institutions in the development of their disaster preparedness, and might guide scholars in further research aimed at understanding the working mechanisms of disaster preparedness. Currently, little consensus exists on the aim of disaster preparedness and the best way to realize them in different circumstances. In order to make preparedness activities as effective as possible, it is important to strengthen the scientific evidence base.

\section{Supplementary Material}

To view supplementary material for this article, please visit https:// doi.org/10.1017/ S1049023X19005181

\section{References}

1. UNISDR. Disaster Statistics. https://www.unisdr.org/we/inform/disaster-statistics. Published March 6, 2015. Accessed April 5, 2018

2. Integrated Regional Information Networks. Disaster reduction and the human cost of disaster. https://www.humanitarianlibrary.org/sites/default/files/2014/02/IRIN_DisasterReduction.pdf. Published 2005. Accessed November 8, 2018. 
Defining and Operationalizing Disaster Preparedness in Hospitals: A Systematic Literature Review: Verheul, M.L.M.I, Dückers, M.L.A. Prehospital and Disaster Medicine: 2020, 35(1), p.

3. EM-DAT database. The Emergency Events Database. https://www.emdat.be/emdat_db. Published 2009. Accessed November 11, 2018.

4. Bayntun C, Rockenschaub G, Murray V. Developing a health system approach to disaster management: a qualitative analysis of the core literature to complement the WHO Toolkit for assessing health-system capacity for crisis management. PLoS Curr. 2012;4.

5. Djalali A, Della Corte F, Foletti M, et al. Art of disaster preparedness in European Union: a survey on the health systems. PLoS Curr. 2014;6.6. Dhawan R, Mehrotra S, Basukala S. Role of hospitals medical science role of hospitals in disasters. Int J Sci Res. 2015;4(12):451-452.

7. Hanfling D, Altevogt BM, Gostin LO. A framework for catastrophic disaster response. JAMA. 2015;308(7):675-676.

8. Daily E, Padjen P, Birnbaum M. A review of competencies developed for disaster healthcare providers: limitations of current processes and applicability. Prehosp Disaster Med. 2010;25(5):387-395.

9. Asch SM, Stoto M, MendesM, et al. A review of instruments assessing public health preparedness. Public Health Rep. 2005;120(5):532-542.

10. Greenwood E. New directions in delinquency research: a commentary on a study by Bernard Lander. Soc Serv Rev. 2009;30(2):147-157.

11. Fraser MR. After 5 years of public health preparedness, are we ready yet? J Public Health Manag Pract. 2001;13(1):3-6.

12. Nelson C, Lurie N, Wasserman J. Assessing public health emergency preparedness: concepts, tools, and challenges. Annu Rev Public Health. 2007;28:1-18.

13. Barbera JA, Yeatts DJ, Macintyre AG. Challenge of hospital emergency preparedness: analysis and recommendations. Disaster Med Public Health Prep.2009;3(Supplement 1).

14. Nelson C, Lurie N, Wasserman J, Zakowski S. Conceptualization and defining public health emergency preparedness. Am J Public Health. 2007;97:S9-11.

15.Kaji AH, Koenig KL, Lewis RJ. Current hospital disaster preparedness. JAMA. 2007;298(18):2188-2190.

16. Slepski LA. Emergency preparedness: concept development for nursing practice. Nurs Clin North Am. 2005;40(3):419-430.

17. Olivieri C, Ingrassia PL, Della Corte F, et al. Hospital preparedness and response in CBRN emergencies. Eur J Emerg Med. 2017;24(5):366-370.

18. Harrison JP, Harrison RA, Piermattei HJ. The role of emergency medical planning in disaster response. Int J Public Pol. 2008;3:354-365.

19. Archer F, Synaeve G. International guidelines and standards for education and training to reduce the consequences of events that may threaten the health status of a community. Prehosp Disaster Med. 2007;22(2):120-130.

20. UNISDR. Terminology on disaster. https://www.unisdr.org/we/inform/terminology. Published February 2, 2017. Accessed November 11, 2018.

21. Tang R. Evaluation of hospital preparedness for public health emergencies in Sichuan (China). PhD thesis; Queensland University of Technology: Queensland, Australia. 2015.

22. Paganini M, Borrelli F, Cattani J, et al. Assessment of disaster preparedness among emergency departments in Italian hospitals: a cautious warning for disaster risk reduction and management capacity. Scand J Trauma Resusc Emerg Med. 2016;24(1):1-8.

23. Ciottone G, Keim ME. Disaster preparedness. In: Ciottone GR. Disaster Medicine. 2nd ed. Philadelphia, Pennsylvania USA: Elsevier Health Science; 2006:200-214.

24. Baack S, Alfred D. Nurses' preparedness and perceived competence in managing disasters. J Nurs Scholarsh. 2013;45(3):281-287.

25. WHO. Hospital emergency response checklist. http://www.euro.who.int/ data/ assets/pdf_file/0008/268766/Hospital-emergency-response-checklist-Eng.pdf. Published 2011. Accessed September 21, 2018.

26. WHO. A strategic framework for emergency preparedness. http://apps.who.int/iris/ bitstream/10665/254883/1/9789241511827-eng.pdf. Published 2017. Accessed October 9, 2018.

27. Oxford English Dictionary. http://www.oed.com. Accessed September 8, 2018.

28. Zhong S, Hou X-Y, Clark M, et al. Disaster resilience in tertiary hospitals: a crosssectional survey in Shandong Province, China. BMC Health Serv Res. 2014;14(1):135. 
Defining and Operationalizing Disaster Preparedness in Hospitals: A Systematic Literature Review: Verheul, M.L.M.I, Dückers, M.L.A. Prehospital and Disaster Medicine: 2020, 35(1), p.

29. Janati A, Sadeghi-bazargani H, Hasanpoor E, Sokhanvar M, HaghGoshyie E, Salehi A. Emergency response of Iranian hospitals against disasters: a practical framework for improvement. Disaster Med Public Health Prep. 2017;(August):1-6.

30. Djalali A, Castren M, KhankehH, et al. Hospital disaster preparedness as measured by functional capacity: a comparison between Iran and Sweden. Prehosp Disaster Med. 2013;28(5):454-461.

31. Adini B, Laor D, Hornik-Lurie T, Schwartz D, Aharonson-Daniel L. Improving hospital mass casualty preparedness through ongoing readiness evaluation. Am J Med Qual. 2012;27(5):426-433.

32. Mcarthy ML, Brewster P. Consensus and tools needed to measure health care emergency management capabilities. Disaster Med Public Health Prep. 2009;3(3): S45-S51.

33. Chand AM, Loosemore M. A socio-ecological analysis of hospital resilience to extreme weather events. Cons Manag Econ. 2015;33(11-12):907-920.

34. Hick JL, Hanfling D, Cantrill S V. Allocating scarce resources in disasters: emergency department principles. Ann Emerg Med. 2012;59(3):177-187.

35. Kaji AHAH, Langford V, Lewis RJRJ. Assessing hospital disaster preparedness: a comparison of an on-site survey, directly observed drill performance, and video analysis of teamwork. Ann Emerg Med. 2008;52(3):195-201.e12.

36. Adini B, Goldberg A, Laor D, Cohen R, Zadok R, Bar-Dayan Y. Assessing levels of hospital emergency preparedness. Prehosp Disaster Med. 2006;21(6):451-457.

37. Tang R, Fitzgerald G, Hou XY, Wu YP. Building an evaluation instrument for china's hospital emergency preparedness: a systematic review of preparedness instruments. Disaster Med Public Health Prep. 2014;8(1):101-109.

38. Soremekun OA, Zane RD, Walls A, Allen MB, Seefeld KJ, Pallin DJ. Cancellation of scheduled procedures as a mechanism to generate hospital bed surge capacity: a pilot study. Prehosp Disaster Med. 2011;26(3):224229.

39. Gillett B, Silverberg M, Roblin P, Adelaine J, Valesky W, Arquilla B. Computer-facilitated assessment of disaster preparedness for remote hospitals in a long-distance, virtual tabletop drill model. Prehosp Disaster Med. 2011;26(3): 230-233.

40. Dobalian A, Stein JA, Radcliff TA, et al. Developing valid measures of emergency management capabilities within US Department of Veterans Affairs hospitals. Prehosp Disaster Med. 2016;31(5):475-484.

41. Zhong S, Clark M, Hou X-YY, Zang Y-LL, Fitzgerald G. Development of hospital disaster resilience: conceptual framework and potential measurement. Emerg Med J. 2014;31(11):930-938.

42. Christian MD,Kollek D, Schwartz B. Emergency preparedness: what every health care worker needs to know. CJEM. 2005;7(5):330-337.

43. Adini B, Goldberg A, Cohen R, Laor D, Bar-Dayan Y. Evidence-based support for the all-hazards approach to emergency preparedness. Isr J Health Policy Res. 2012;1(1):1-7.

44. Kuntz S, Smilie J, Wang J. How ready are we? Northwest Public Health. 2005;7.

45. Kosashvili Y, Daniel LA, Peleg K, Horowitz A, Laor D, Blumenfeld A. Israeli hospital preparedness for terrorism-related multiple casualty incidents: can the surge capacity and injury severity distribution be better predicted? Injury. 2009;40(7):727-731.

46. Hick JL, Barbera JA, Kelen GD. Refining surge capacity: conventional, contingency and crisis capacity. Disaster Med Public Health Prep. 2009;3(2):S59-67.

47. Zhong S, Clark M, Hou XY, Zang Y, Fitzgerald G. Validation of a framework for measuring hospital disaster resilience using factor analysis. Int J Environ Res Public Health. 2014;11(6):635-653.

48. Verheul ML, Dückers MLA, Visser BB, Beerens RJ, Bierens JJLM. Disaster exercises to prepare hospitals for mass-casualty incidents: does it contribute to preparedness or is it ritualism? Prehosp Disaster Med. 2018;33(4):387-393.

49. Hsu EB, Thomas TL, Bass EB, Whyne D, Kelen GD, Green GB. Healthcare worker competencies for disaster training. BMC Med Educ. 2006;6(1):19.

\section{Tables and figures}


Defining and Operationalizing Disaster Preparedness in Hospitals: A Systematic Literature Review: Verheul, M.L.M.I, Dückers, M.L.A. Prehospital and Disaster Medicine: 2020, 35(1), p.

Table 1: Search Strategy

\begin{tabular}{|c|}
\hline $\begin{array}{c}\text { 1. hospital or hospitals } \\
\text { and }\end{array}$ \\
$\begin{array}{c}\text { 2. disaster* or "mass casualty incident" or emergency } \\
\text { and }\end{array}$ \\
3. prepar* or planning or "disaster planning" \\
and \\
4. operationalization or definition or define* or concept* or theory or \\
framework
\end{tabular}

Table 2: Additional Search Strategy

\begin{tabular}{|c|}
\hline $\begin{array}{c}\text { 1. hospital or hospitals } \\
\text { and }\end{array}$ \\
$\begin{array}{c}\text { 2. disaster* or "mass casualty incident" or emergency } \\
\text { and }\end{array}$ \\
3. resilience or "surge capacity" or readiness \\
and \\
4. operationalization or definition or define* or concept* or theory or \\
framework
\end{tabular}


Defining and Operationalizing Disaster Preparedness in Hospitals: A Systematic Literature Review: Verheul, M.L.M.I, Dückers, M.L.A. Prehospital and Disaster Medicine: 2020, 35(1), p.

Table 3. The 13 Original Definitions of Disaster Preparedness

\begin{tabular}{|c|c|}
\hline Reference & Definition \\
\hline (8) & Capable of meeting the challenges. \\
\hline (9) & $\begin{array}{l}\text { The readiness of agencies to respond to } \\
\text { emergent acute threats to the public health. }\end{array}$ \\
\hline (11) & $\begin{array}{l}\text { The public health system can effectively respond } \\
\text { to a health emergency such as pandemic } \\
\text { influenza. }\end{array}$ \\
\hline (12) & $\begin{array}{l}\text { The capacity of the public health system to } \\
\text { reduce morbidity and mortality arising from } \\
\text { intentional terrorist attacks, large-scale } \\
\text { transmissions of naturally occurring agents, or } \\
\text { natural disasters. }\end{array}$ \\
\hline (13) & $\begin{array}{l}\text { The ability to effectively maintain hospital } \\
\text { operations, sustain a medically safe } \\
\text { environment, and adequately address the } \\
\text { increased and potentially unusual medical needs } \\
\text { of the affected population. }\end{array}$ \\
\hline (14) & $\begin{array}{l}\text { The capacity of public health and health care } \\
\text { systems, communities, and individuals to } \\
\text { prevent, protect against, quickly respond to, and } \\
\text { recover from health emergencies, particularly } \\
\text { those whose scale, timing, or unpredictability } \\
\text { threatens to overwhelm routine capabilities. }\end{array}$ \\
\hline (15) & $\begin{array}{l}\text { Health care system's ability to manage a sudden } \\
\text { or rapidly progressive influx of patients within the } \\
\text { currently available resources at a given point in } \\
\text { time. }\end{array}$ \\
\hline$(16)$ & $\begin{array}{l}\text { The readiness to react constructively to threats } \\
\text { from the environment in a way that minimizes the } \\
\text { negative consequences of the impact for the } \\
\text { health and safety of individuals and the integrity } \\
\text { and functioning of physical structures and } \\
\text { systems. }\end{array}$ \\
\hline (17) & $\begin{array}{l}\text { Ensuring the appropriate management of } \\
\text { disasters. }\end{array}$ \\
\hline (18) & $\begin{array}{l}\text { The ability to respond to a disaster, crisis, or } \\
\text { emergency situation. }\end{array}$ \\
\hline (19) & $\begin{array}{l}\text { Preparedness is the aggregate of all measures } \\
\text { and policies taken by humans before the event } \\
\text { occurs that reduces the damage that otherwise } \\
\text { would have been caused by the event. }\end{array}$ \\
\hline (20) & $\begin{array}{l}\text { The knowledge and capacities developed by } \\
\text { governments, professional response and } \\
\text { recovery organizations, communities, and } \\
\text { individuals to effectively anticipate, respond to, } \\
\text { and recover from the impacts of likely, imminent, } \\
\text { or current hazard events or conditions. }\end{array}$ \\
\hline (21) & $\begin{array}{l}\text { The planning and actions that enable hospitals to } \\
\text { prevent, protect against, quickly respond to, and } \\
\text { recover from public health emergencies in a } \\
\text { timely, coordinated, and effective way. }\end{array}$ \\
\hline
\end{tabular}


Defining and Operationalizing Disaster Preparedness in Hospitals: A Systematic Literature Review:

Verheul, M.L.M.I, Dückers, M.L.A. Prehospital and Disaster Medicine: 2020, 35(1), p.

Table 4: The 22 Original Operationalizations of Preparedness

Abbreviations: $\mathrm{MCl}$, mass-casualty incident; SOP, standard operating procedure.

\begin{tabular}{|c|c|}
\hline Reference & Operationalization/Conceptualization of "Preparedness in Hospitals" \\
\hline (7) & $\begin{array}{l}\text { The three critical components of catastrophic disaster preparedness are: (1) development of crisis standard of care; (2) development } \\
\text { of a systems-approach that ensures integration among key stakeholders; and (3) meaningful engagement between health care } \\
\text { professionals and the public. }\end{array}$ \\
\hline (8) & $\begin{array}{l}\text { Education and training are the cornerstones of disaster preparedness. The development of a health care workforce capable of meeting } \\
\text { the challenges inherent in these threats. }\end{array}$ \\
\hline (14) & $\begin{array}{l}\text { Risk assessment, legal climate, assign roles, command system, public engagement, epidemiology functions, laboratory functions, } \\
\text { mitigation strategies, mass surge, public information, and expert and fully trained staff. }\end{array}$ \\
\hline (17) & Planning and organization, safety and security, SOP, communication, resources, decontamination, and medical management. \\
\hline (24) & From EPIQ-tool: command and control, emergency plan, drills, and communication. \\
\hline (25) & $\begin{array}{l}\text { Nine key domains including command and control, communication, safety and security, triage, surge capacity, conjunction of } \\
\text { essential services, human resources, logistics and supply management, and post-disaster recovery. }\end{array}$ \\
\hline (32) & $\begin{array}{l}\text { Safety and security, continuity, communication, volunteer management, resource management, surge, support of external entities, } \\
\text { incident management, and planning. }\end{array}$ \\
\hline (33) & $\begin{array}{l}\text { Building the technical and managerial capacities to cope with incidents through the development of disaster management plans; } \\
\text { emergency exercises and training; early waming systems; emergency communication systems; emergency personnel/contact lists; } \\
\text { mutual aid agreements; and public information and education. }\end{array}$ \\
\hline (34) & $\begin{array}{l}\text { Preparedness activities (planning, caching of supplies) increase the capacity of the system to provide conventional and contingency } \\
\text { care, increasing the volume of patients who can be accommodated before shifting to crisis care, a shift that may compromise patient } \\
\text { outcomes. }\end{array}$ \\
\hline (35) & $\begin{array}{l}\text { Command and control, contact lists, engagement with the public, communication, mutual aid agreements, continuity strategies, } \\
\text { education of the public, safety procedures, decontamination unit, surge capacity, and plans. }\end{array}$ \\
\hline (36) & $\begin{array}{l}\text { Preparedness assessments should include: (1) elements of disaster planning; (2) emergency coordination; (3) communication; } \\
\text { (4) training; (5) expansion of hospital surge capacity; (6) personnel; (7) availability of equipment; (8) stockpiles of medical supplies; and } \\
\text { (9) expansion of laboratory capacities. The preparedness pyramid identifies: (1) planning and policies; (2) equipment and } \\
\text { infrastructure; (3) knowledge and capabilities of staff; and (4) training and drills as the major components of maintaining a high-level of } \\
\text { preparedness. }\end{array}$ \\
\hline (37) & $\begin{array}{l}\text { (1) Operational capability improvement; (2) expert and fully staffed workforce; (3) infrastructure, equipment, and other supplies; } \\
\text { and (4) plans and management. }\end{array}$ \\
\hline (38) & $\begin{array}{l}\text { In-patient surge capacity, the ability to generate staffed and ready in-patient beds in the event of an unanticipated surge in demand for } \\
\text { in-patient health care services due to events such as mass-casualty incidents or pandemics, is an essential component of public } \\
\text { health preparedness. }\end{array}$ \\
\hline (39) & $\begin{array}{l}\text { HEAT: Factors found to contribute to effective hospital emergency response include: (1) use of the hospital incident command system; } \\
\text { (2) antidote and emergency drug caches; (3) physical security and facility lockdown procedures; and (4) basic health care professional } \\
\text { knowledge of chemical, biological, radiologic, nuclear, and high-yield explosive emergency response. }\end{array}$ \\
\hline (40) & $\begin{array}{l}\text { The six mission areas are: program management; incident management; safety and security; resilience and continuity; medical surge; } \\
\text { and support to external requirements. }\end{array}$ \\
\hline (41) & $\begin{array}{l}\text { Emergency leadership; community cooperation and communication; disaster plans; disaster stockpiles and logistics management; } \\
\text { emergency staff; and emergency training and drills. }\end{array}$ \\
\hline (42) & Preparedness encompasses planning, training, equipping, and exercises. \\
\hline$(43)$ & SOPs, training and drills, knowledge of staff, infrastructure, and equipment. \\
\hline (44) & $\begin{array}{l}\text { Preparedness/Planning/Readiness: } \\
\text { - Agency staff includes an Emergency Response Coordinator. } \\
\text { - Strategic emergency preparedness planning is a part of agency activities. } \\
\text { - Emergency plan is in place; emergency staffing plan for } 24 / 7 \text { coverage. } \\
\text { - Job descriptions for emergency; written plans include roles and responsibilities. } \\
\text { - Emergency contact directory accessible } 24 / 7 \text {; updated at least annually. } \\
\text { - Key personnel/external partner test: acknowledges contact within } 30 \text { minutes. } \\
\text { - Emergency plans tested through an exercise or real event. } \\
\text { - A local Strategic National Stockpile plan in place. }\end{array}$ \\
\hline (45) & Hospital's preparedness for terrorist-related $\mathrm{MCl}$ comprises organizational infrastructure, staff training, manpower, and equipment. \\
\hline (46) & $\begin{array}{l}\text { Command, control, communication, coordination, continuity of operations, and community infrastructure. Crisis capacity - Adaptive } \\
\text { spaces, staff, and supplies are notconsistent with usual standards of care butprovide sufficiency of care in the setting of a catastrophic } \\
\text { disaster (ie, provide the best possible care to patients given the circumstances and resources available). }\end{array}$ \\
\hline$(47)$ & $\begin{array}{l}\text { Eight domains: } 1 \text {. Emergency command, communication, and cooperation system; } 2 \text {. Disaster plans; } 3 \text {. Disaster stockpiles and } \\
\text { management; } 4 \text {. Emergency staff; } 5 \text {. Emergency training and drills; } 6 \text {. Emergency services and surge capacity; } 7 \text {. Hospital safety } \\
\text { standard and procedures; and } 8 \text {. Recovery and adaptation strategies. }\end{array}$ \\
\hline
\end{tabular}


Defining and Operationalizing Disaster Preparedness in Hospitals: A Systematic Literature Review: Verheul, M.L.M.I, Dückers, M.L.A. Prehospital and Disaster Medicine: 2020, 35(1), p.

\section{Table 5: Operationalization of Preparedness: Nine Components}

${ }^{a}$ In this table, mutual aid agreements (mentioned by five authors)and contact lists (mentioned by three authors) are categorizedunder the component of disaster plans and protocols.

\begin{tabular}{|l|l|c|}
\hline & Component & \# Mentioned \\
\hline 1 & $\begin{array}{l}\text { Disaster Plans or Protocols (including } \\
\text { Standard Operating Procedures) }\end{array}$ & $26^{\mathrm{a}}$ \\
\hline 2 & Available Equipment & 18 \\
\hline 3 & Education, Training, and Exercises & 14 \\
\hline 4 & Command, Control, and Coordination & 12 \\
\hline 5 & Crisis Communication Strategies & 10 \\
\hline 6 & Available Staff & 9 \\
\hline 7 & Public Engagement Models & 6 \\
\hline 8 & Safety and Security & 6 \\
\hline 9 & Continuity Strategies & 5 \\
\hline
\end{tabular}

Table 6: Aims of Preparedness

\begin{tabular}{|c|c|}
\hline Ref & Aim of Preparedness \\
\hline (8) & $\begin{array}{l}\text { Meeting the numerous and varied health needs of } \\
\text { populations affected by disasters. }\end{array}$ \\
\hline$(12)$ & $\begin{array}{l}\text { The desired outcome of a response is the maintenance } \\
\text { or restoration of affected (or potentially affected) } \\
\text { populations' health status. }\end{array}$ \\
\hline (19) & To reduce the damage of an event. \\
\hline (23) & $\begin{array}{l}\text { Objectives of preparedness for health emergencies } \\
\text { have been offered as follows: } \bullet \text { Prevent morbidity and } \\
\text { mortality; } \bullet \text { Provide care for casualties; } \bullet \text { Manage } \\
\text { adverse climatic and environmental conditions; } \bullet \text { Ensure } \\
\text { restoration of normal health; } \bullet \text { Reestablish health } \\
\text { services; } \bullet \text { Protect staff; } \bullet \text { Protect public health and } \\
\text { medical assets. }\end{array}$ \\
\hline (29) & To deal with victims and treat their injuries. \\
\hline (30) & $\begin{array}{l}\text { To sustain a safe environment for patients as well as for } \\
\text { staff, continue effective operations, and adequately } \\
\text { provide for the medical needs of casualties in the face of } \\
\text { a disaster. }\end{array}$ \\
\hline$(47)$ & $\begin{array}{l}\text { Hospitals play an important role during disasters, as they } \\
\text { provide "lifeline" services to reduce disaster-associated } \\
\text { mortality and morbidity, and thus minimize the impact of } \\
\text { disasters on the community. }\end{array}$ \\
\hline
\end{tabular}


Defining and Operationalizing Disaster Preparedness in Hospitals: A Systematic Literature Review: Verheul, M.L.M.I, Dückers, M.L.A. Prehospital and Disaster Medicine: 2020, 35(1), p.

Figure 1. PRISMA Represenstation.

Research Question: How is disaster preparedness in hospitals defined and operationalized?

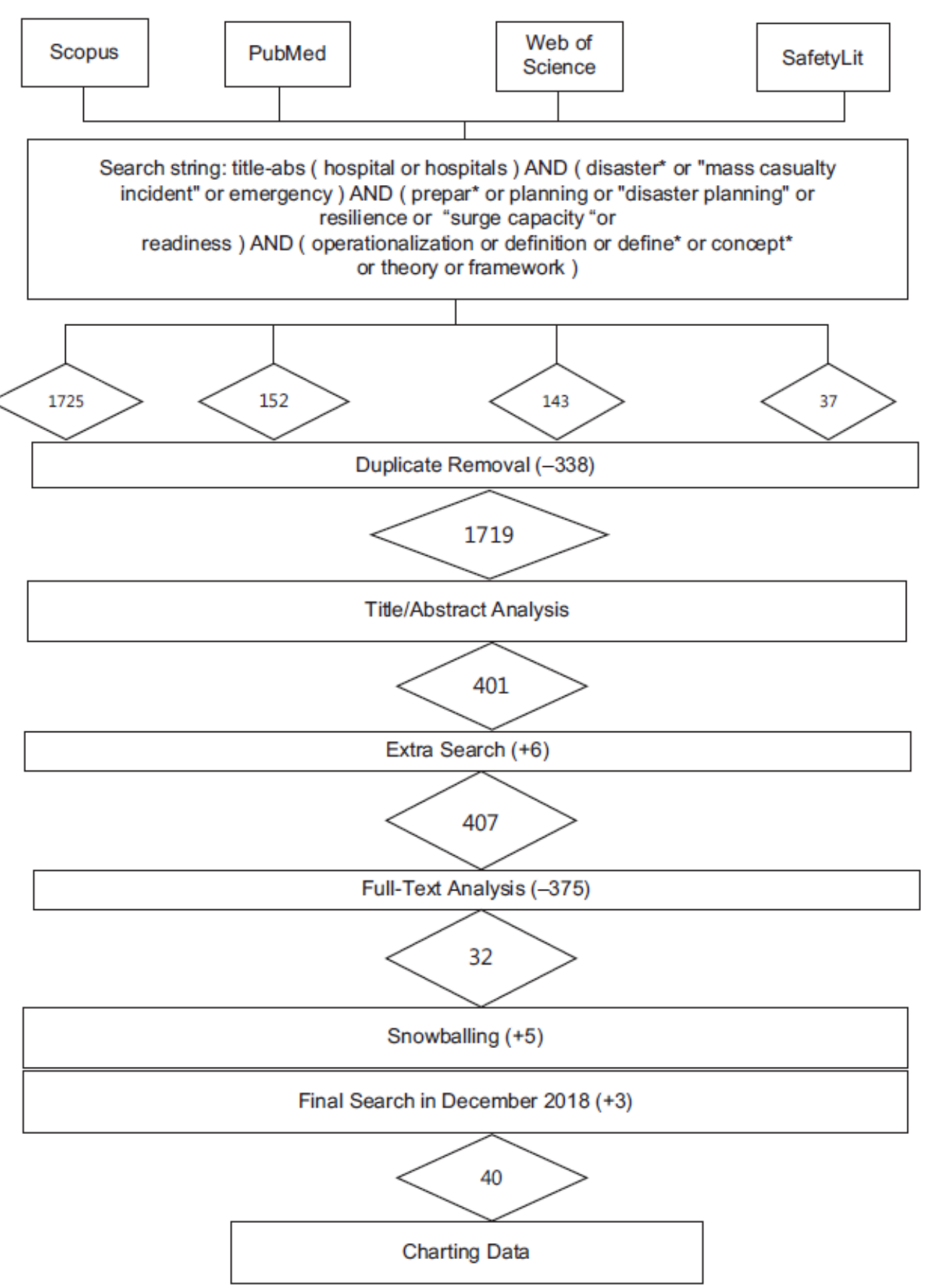


Defining and Operationalizing Disaster Preparedness in Hospitals: A Systematic Literature Review: Verheul, M.L.M.I, Dückers, M.L.A. Prehospital and Disaster Medicine: 2020, 35(1), p.

Figure 2: Nonagon for Disaster Preparedness in Hospitals.

Note: The nine components of preparedness identified in this review and their possible interrelations are shown at the center of the model. The status of preparedness and its components is likely to depend on conditions, including education, training, and exercises. The latter might influence the conditions as well. The model itself can serve as a planning and evaluation instrument, or it might serve study purposes. This visualization is one way to structure different factors and the relations between them that needs to be further developed and tested. Alternative interpretations are possible.

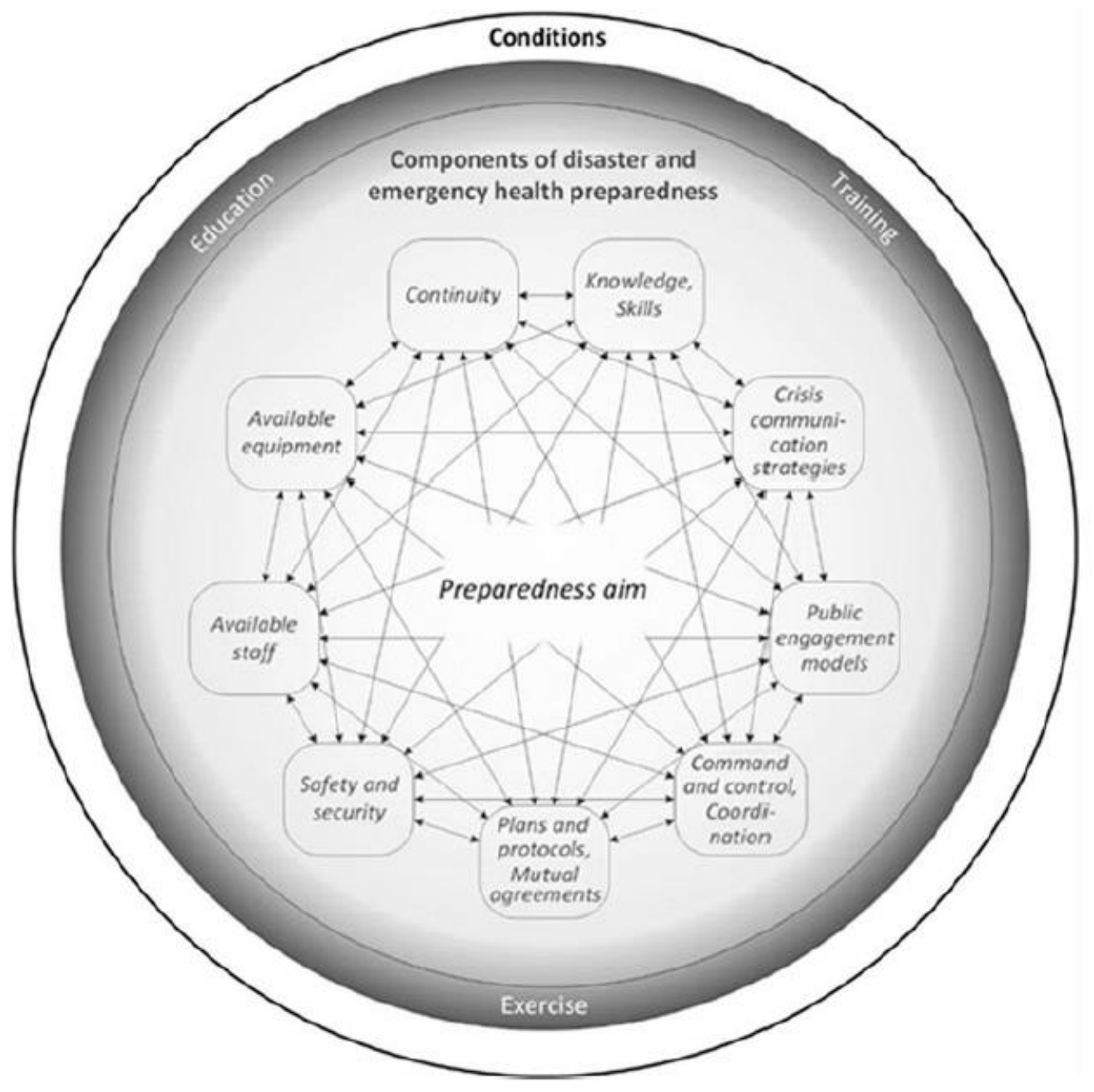

